\title{
Penerapan Model Triple Helix Dalam Meningkatkan Minat Berwirausaha Masyarakat Kelurahan Rabangodu Selatan Pada Masa Pandemi Covid-19
}

\author{
Randitha Missouri ${ }^{1 *}$, Zumhur Alamin $^{2}$, Ulil Azmin ${ }^{3}$ \\ ${ }^{1,2,3)}$ Institut Agama Islam Muhammadiyah Bima \\ *Corresponding Author: randitha44@gmail.com
}

\begin{abstract}
ABSTRAK - Penelitian ini bertujuan untuk menemukan dampak penerapan model triple helix dalam meningkatkan minat berwirausaha masyarakat Rabangodu Selatan pada masa pandemi covid-19. Penelitian ini menggunakan metode kualitatif deskriptif. Pengumpulan data dilakukan dengan tiga cara yaitu, wawancara, observasi, dan studi dokumen. Analisis data menggunakan interactive model, yaitu dengan mengumpulkan data, mereduksi, menyajikan data, dan menarik kesimpulan. Pengujian keabsahan data menggunakan triangulasi teknik dan sumber. Waktu penelitian empat bulan, dimulai dari Februari hingga Mei 2021 berlokasi di Rabangodu Selatan Kota Bima. Hasil penelitian menunjukkan bahwa model triple helix belum mampu meningkatkan minat berwirausaha masyarakat kelurahan Rabangodu Selatan pada masa pandemi covid-19 ditinjau dari tiga faktor, yaitu: (1) faktor personal, (2) faktor environment, (3) faktor sosiological. Rekomendasi bagi pemerintah Kota Bima dan kelurahan Rabangodu Selatan dapat menyiapkan wadah guna mengembangkan minat berwirausaha masyarakat, pengadaan sarana dan prasarana memadai, peminjaman modal usaha, memberikan akses informasi, melakukan kerjasama dengan perusahaan dan perguruan tinggi di bidang kewirausahaan, serta melakukan monitoring dan evaluasi berkelanjutan. Sedangkan untuk perguruan tinggi lebih fokus dalam melakukan pengabdian masyararakat di bidang kewirausahaan. Swasta atau perusahaan lebih berperan aktif dalam berbagi ilmu, informasi, memberikan pinjaman modal dan memberdayakan masyarakat untuk menjadi mitra usaha, serta melakukan pembinaan dan pelatihan.
\end{abstract}

Kata Kunci - Model Triple Helix; Minat Berwirausaha; Pandemi Covid-19

\section{PENDAHULUAN}

Pandemi covid-19 berdampak pada perekonomian Indonesia. Badan Pusat Statistik (BPS) mencatat penurunan pertumbuhan ekonomi Indonesia pada triwulan II (April-Mei-Juni) 2020 menjadi negatif (-5.32\%). Sebelum pandemi, pertumbuhan ekonomi Indonesia pada triwulan I (Januari-Februari-Maret) tercatat mencapai $2.97 \%$. Solusi yang ditawarkan terhadap dampak penurunan ekonomi di masa pandemi covid19 adalah melalui percepatan belanja pemerintah atau menambah alokasi anggaran bantuan sosial dan bantuan langsung tunai. DPR dengan fungsi pengawasan perlu mendesak pemerintah guna membuat kebijakan yang diarahkan pada upaya mendorong percepatan pemulihan ekonomi nasional. ${ }^{1}$

${ }^{1}$ Wuryandani, “Dampak Pandemi Covid-19 terhadap Pertumbuhan Ekonomi Indonesia 2020 dan Solusinya”, Kajian Strategis terhadap Isu Aktual dan Strategis, XII(15), 19-24. 
Menteri keuangan Sri Mulyani Indrawati dalam kegiatan rapat kerja menteri keuangan bersama anggota Komite XI DPR di Kompleks Parlemen, Senayan, Jakarta, Senin, 29 Juni 2020 tentang tiga masalah ekonomi yang disebabkan pandemi covid-19, 1) pandemi menimbulkan masalah sosial di tengah masyarakat, 2) ketidakpastian di tengah pandemi membuat tingkat investasi melemah, dan 3) perekonomian dunia melemah, sehingga kinerja ekspor juga melemah dan terjadi penurunan harga komoditas, minyak, batu bara, sampai Crude Palm Oil (CPO). ${ }^{2}$

Kota Bima merupakan salah satu kota di provinsi Nusa Tenggara Barat, terdiri dari lima kecamatan yaitu Raba, Rasanae Barat, Rasanae Timur, Asakota, dan Mpunda. Laju pertumbuhan ekonomi Kota Bima tahun 2008 sebesar 4.70\%, tahun 2019 sebesar $5.15 \%$, dan tahun 2020 sebesar $-4.95 \%{ }^{3}$. Pandemi covid-19 masuk di Kota Bima pada akhir tahun 2019. Berdasarkan data Badan Pusat Statistik Kota Bima, laju ekonomi pada awal pandemi terlihat stabil dan mengalami peningkatan dibandingkan tahun sebelumnya, namun terjadi penurunan laju ekonomi masyarakat Kota Bima tahun 2020 menjadi $-4.95 \%$. Hal ini membuktikan bahwa pandemi covid-19 sangat mempengaruhi laju pertumbuhan ekonomi masyarakat Kota Bima. Pemerintah Kota Bima perlu mengambil langkah konkrit di masa pandemi covid-19, bukan hanya pada persoalan pemberantasan virus corona, namun juga pada peningkatan kesejahteraan ekonomi masyarakat. Corona dan ekonomi merupakan hal yang saling berhubungan. Ekonomi membaik, kebutuhan terpenuhi, imun tubuh meningkat, dampaknya corona tidak akan mampu menyerang.

Pemerintah Propinsi NTB dalam website-nya mengutip data dari dinas kesehatan-NTB menjelaskan bahwa pada 29 Maret 2021 pukul 23:13 jumlah kasus rawat di NTB sebanyak 944 orang $(8.70 \%)$, kasus sembuh sebanyak 9436 orang $(87.00 \%)$, dan kasus meninggal sebanyak 466 (4.30\%). Data Kota Bima sampai tanggal 3 Februari 2021 termasuk lima besar wilayah di NTB dengan jumlah kasus positif corona, yaitu sebanyak 771 kasus, namun tidak termasuk dalam lima besar wilayah di NTB dengan kasus kematian yang disebabkan virus corona. ${ }^{4}$

Rabangodu Selatan merupakan salah satu kelurahan di kecamatan Raba Kota Bima-Nusa Tenggara Barat. Berdasarkan hasil survei pra penelitian yang dilaksanakan pada 28 sampai dengan 30 Maret 2021 pada masyarakat Rabangodu Selatan, terdapat beberapa faktor penyebab kurangnya minat masyarakat dalam berwirausaha, 1) modal usaha, 2) antusias masyarakat lebih tinggi pada dunia perkantoran, 3) pemerintah kurang aktif dalam melakukan pembinaan di bidang kewirausahaan, 4) perguruan tinggi belum berpartisipasi dalam pengabdian masyarakat di bidang kewirausahaan, 5)

${ }^{2}$ Rahma Anjaeni, "Sri Mulyani ungkap tiga masalah ekonomi yang disebabkan pandemi Covid-19". https://nasional.kontan.co.id/news/sri-mulyani-ungkap-tiga-masalah-ekonomiyang-disebabkan-pandemi-covid-19?page=all Dikutip Pada Tanggal 1 April 2021.

3 BPS Kota Bima, "Kecamatan Raba Dalam Angka 2020", https://bimakota.bps.go.id/publication/2020/09/28/ac0af0b60ed610b921be4419/kecamatanraba-dalam-angka-2020.html Dikutip Pada Tanggal 1 April 2021.

4 Pemerintah Propinsi NTB, "DATA COVID-19 Dinas Kesehatan NTB", https://corona.ntbprov.go.id/ Dikutip Pada Tanggal 1 April 2021. 
pelaku usaha belum terlalu aktif dalam melakukan pendampingan, dan 6) pandemi covid-19 menjadi penyebab keraguan masyarakat dalam mulai berwirausaha. Hasil survei menunjukkan bahwa model triple helix belum diterapkan dengan efektif dan efisien di tengah masyarakat kelurahan Rabangodu Selatan pada masa pandemi covid19.

Pemerintah, perguruan tinggi, dan pelaku usaha sebagai komponen penting belum aktif menunjukkan eksistensi dalam meningkatkan kesejahteraan ekonomi masyarakat khususnya pada masa pandemi covid-19. Pandemi covid-19 bukan hanya meninggalkan ketidakpastian dalam bidang ekonomi, tapi hampir di semua lini kehidupan. Jumlah penduduk yang bekerja di sektor non pertanian pada kelurahan Nitu yaitu sebanyak 233 orang, kelurahan Rontu sebanyak 230 orang, kelurahan Rabangodu Selatan sebanyak 112 orang, kelurahan Rabangodu Utara sebanyak 483 orang, kelurahan Penaraga sebanyak 552 orang, kelurahan Rabadompu Barat sebanyak 424 orang, kelurahan Rabadompu Timur sebanyak 515 orang, kelurahan Kendo sebanyak 185 orang, kelurahan Penanae sebanyak 428 orang, kelurahan Rite sebanyak 384 orang, kelurahan Ntobo sebanyak 259 orang. Masyarakat Rabangodu Selatan merupakan masyarakat yang paling sedikit bekerja di sektor non pertanian (perdagangan, industri, pertambangan, angkutan, dan kerajinan) dibandingkan sepuluh kelurahan lain di kecamatan Raba-Kota Bima.

Jumlah Usaha Mikro Kecil dan Menengah (UMKM) Kota Bima tahun 2021 sebanyak 2325 dan jumlah UMKM Kecamatan Raba tahun 2021 sebanyak 299 (Kementerian Koperasi dan Usaha Kecil dan Menengah Republik Indonesia, 2021). Jumlah UMKM Kota Bima tahun 2018 sebanyak 3.935 unit, tahun 2019 sebanyak 4.669 unit, dan tahun 2020 sebanyak 3.759 unit $^{5}$. Berdasarkan data tersebut dapat disimpulkan bahwa jumlah UMKM Kota Bima awal masa pandemi tahun 2019 mengalami peningkatan dibandingkan tahun sebelum pandemi covid-19 (2018). Pertambahan UMKM sebanyak 734 unit, namun jumlah UMKM mengalami penurunan di masa pandemi covid-19 (2020) dibandingkan awal pandemi tahun 2019, penurunan jumlah UMKM Kota Bima sebanyak 910 unit. Jumlah UMKM kelurahan Rabangodu Selatan sebanyak 198 unit dengan pembagian kelompok usaha industri sebanyak 14 unit, perdagangan 107 unit, fashion sebanyak 15 unit, agrobisnis sebanyak 1 unit, kuliner sebanyak 44 unit, peternakan dan perikanan sebanyak 7 unit, dan bidang lain sebanyak 10 unit. $^{6}$

\section{TINJAUAN PUSTAKA}

\section{Triple Helix}

Triple helix muncul pada pertengahan 1990-an, saat universitas dan industri dihimbau oleh pembuat kebijakan untuk bekerjasama demi kemaslahatan masyarakat guna menghasilkan komersialisasi pengetahuan baru. Makalah pertama, Etzkowitz \& Leydesdorff (1995), The Triple Helix-University-Hubungan Industri-Pemerintah:

\footnotetext{
${ }^{5}$ Dinas Koperindag Kota Bima, "Rekap Data 2018-2021 Untuk Inspektorat".

${ }^{6}$ Dinas Koperindag Kota Bima, "Data Rabangodu Selatan”.
} 
Laboratorium untuk Pembangunan Ekonomi Berbasis Pengetahuan muncul setelah partisipasi Etzkowitz (1994) dalam lokakarya di Amsterdam berjudul Ekonomi Evolusioner dan Teori Chaos: Arah Baru dalam Teknologi Studi. Metafora dari Triple helix muncul setelah itu dalam diskusi tentang pengorganisasian tindak lanjut konferensi dengan judul tersebut di Amsterdam pada Januari 1996. ${ }^{7}$

Nelson \& Winter (1982), Dosi, dkk. (1988), dan Leydesdorff \& Besselaar (1994) ${ }^{8}$ menjelaskan bahwa,

A "triple helix" of academic-industry-government relations is likely to be a key component of any national or multi-national innovation strategy in the late twentieth century. The focus on interactions between institutions of fundamental research "on the supply side" and corporations has not only been reflected in technology policies, but also in technology studies. Linear models of "demand pull" or "technology push" have been superceded by evolutionary models that analyze the developments in terms of network.

Hubungan antara komponen triple helix akademis-industri-pemerintah kemungkinan akan menjadi komponen kunci dari strategi nasional atau multi-nasional akhir abad 20. Fokus pada interaksi antara lembaga penelitian dan perusahaan tidak hanya pada kebijakan teknologi, tetapi juga pada studi teknologi.

Triple helix merupakan suatu pendekatan yang menguraikan tentang bagaimana sebuah inovasi muncul dari adanya hubungan yang seimbang, timbal balik, dan terus menerus dilakukan antar akademisi (perguruan tinggi serta lembaga penelitian dan pengembangan), pemerintah (government), dan para pelaku/ sektor bisnis (entreprises). Sinerginitas ketiga komponen tersebut dikenal dengan istilah ABG (Academic, Business, and Government). ${ }^{9}$

Etzkowitz \& Leydesdorff (2000) ${ }^{10}$ menyatakan bahwa komponen utama triple helix adalah tentang kekuatan antara akademisi, bisnis, dan pemerintah. Kalangan akademisi dengan sumber daya, ilmu pengetahuan, dan teknologi memfokuskan diri menghasilkan berbagai temuan dan inovasi yang aplikatif. Kalangan bisnis melakukan kapitalisasi yang memberikan keuntungan ekonomi dan kemanfaatan bagi masyarakat. Sedang pemerintah menjamin dan menjaga stabilitas hubungan keduanya dengan regulasi kondusif. Model triple helix memaparkan strategi inovasi dan praktek yang dihasilkan oleh kerjasama diantara ketiganya. Teknologi dan akademik menjadi sumber daya yang sangat bernilai dalam perkekonomian. Penerapannya dalam industri dan sosial kemasyarakatan memberikan dampak terhadap pembangunan masyarakat

${ }^{7}$ Helen Lawton Smith \& Loet Leydesdorff, "The Triple Helix in the context of global change: dynamics and challenges", Prometheus, 32:4, 321-336.

${ }^{8}$ Henry Etzkowitz \& Loet Leydesdorff, "The Triple Helix -- University-IndustryGovernment Relations: A Laboratory for Knowledge Based Economic Development" (January 1, 1995). EASST Review, Vol. 14, No. 1, pp. 14-19, 1995.

${ }^{9}$ Sintha Wahjusaputri, dkk, "Model Pengembangan Ekonomi Kreatif Berbasis Triple Helix Bagi UKM Di Provinsi Jawa Barat".

${ }^{10}$ Hamidah Nayati Utami, dkk, "Pemberdayaan Masyarakat dengan Pendekatan Triple Helix untuk Pengembangan Kompetensi Wirausaha Masyarakat Desa Mandiri Energi". Jurnal Ilmiah Administrasi Publik, 5(3), 294-302. 
Persaingan produk yang inovatif membutuhkan transformasi inovasi dari proses internal perusahaam kearah proses eksternal perusahaan termasuk perguruan tinggi. Dalam konteks struktur ekonomi baru yang didasarkan pada pengetahuan, maka universitas memainkan peranan penting sebagai sumber inovasi .

Menurut Etzkowitz (1997) ${ }^{11}$ triple helix adalah bersinerginya tiga aktor sebagai penggerak dalam menggembangkan ekonomi kreatif. Sebagai konsep, gagasan utama Triple helix adalah sinergi kekuatan antara akademisi, bisnis, dan pemerintah. Kalangan akademisi dengan sumber daya, ilmu pengetahuan, dan teknologinya memfokuskan diri untuk menghasilkan berbagai temuan dan inovasi yang aplikatif. Kalangan bisnis melakukan kapitalisasi yang memberikan keuntungan ekonomi dan kemanfaatan bagi masyarakat. Sedang pemerintah menjamin dan menjaga stabilitas hubungan keduanya dengan regulasi kondusif.

\section{Minat Berwirausaha}

Zimmerer, dkk (2008) ${ }^{12}$, menyatakan bahwa salah satu faktor pendorong pertumbuhan kewirausahaan di suatu negara terletak pada peranan universitas melalui penyelenggaraan pendidikan kewirausahaan.

Kewirausahaan adalah semangat, sikap, perilaku, dan kemampuan seseorang dalam menangani usaha atau kegiatan yang mengarah pada upaya mencari, menciptakan serta menerapkan cara kerja, teknologi dan produk baru dengan meningkatkan efisiensi dalam rangka memberikan pelayanan yang lebih baik dan/atau memperoleh keuntungan yang lebih besar ${ }^{13}$. Hendro menyatakan bahwa "wirausaha adalah pelaku utama dalam pembangunan ekonomi dan fungsinya adalah melakukan inovasi atau kombinasi-kombinasi yang baru untuk sebuah inovasi" ${ }^{14}$

Pernyataan serupa juga diungkapkan Bygrave bahwa "Entrepreneur as the person who destryos the existing economic order by introducing new products and services, by creating new forms of organization, or by exploiting new raw materials". Entrepeneur atau wirausaha adalah seseorang yang mampu menciptakan sesuatu yang baru baik barang ataupun jasa dalam suatu organisasi dan mampu mendobrak sistem ekonomi yang ada. Wirausaha (entrepreneur) adalah seseorang yang tangguh melakukan sesuatu. ${ }^{15}$

Terdapat tiga faktor pendorong minat berwirausaha menurut Bygrave yaitu, 1) Faktor personal, menyangkut aspek kepribadian meliputi, ketidakpuasan terhadap pekerjaan seseorang, pemutusan hubungan kerja, tidak ada pekerjaan lain, dorongan karena faktor usia, keberanian menanggung resiko, komitmen atau minat tinggi pada bisnis, 2) Faktor environment, menyangkut hubungan dengan lingkungan fisik, meliputi,

${ }^{11}$ Zul Asfi Arroyhan Daulay, "Strategi Pengembangan Ekonomi Kreatif Dengan Metode Triple Helix (Studi Pada UMKM Kreatif di Kota Medan)", TANSIQ: Jurnal Manajemen Dan Bisnis Islam, 1(1).

12 NI Wedayanti \& I Giantari, "Peran Pendidikan Kewirausahaan Dalam Memediasi Pengaruh Norma Subyektif Terhadap Niat Berwirausaha. E-Jurnal Manajemen Universitas Udayana", 5(1), 255039.

${ }^{13}$ Rusdiana, "Kewirausahaan: Teori dan Praktek", Pustaka Setia.

${ }^{14}$ Hendro, "Dasar-Dasar Kewirausahaan", Jakarta: Erlangga.

${ }^{15}$ Buchari Alma, "Kewirausahaan untuk mahasiswa dan umum", Bandung: Alfabeta. 
persaingan dalam dunia kehidupan, sumber yang bisa dimanfaatkan seperti modal, tabungan, warisan, bangunan, dan lokasi strategis, mengikuti pelatihan kursus bisnis atau inkubator bisnis, kebijakan pemerintah adanya kemudahan lokasi berusaha, fasilitas kredit dan bimbingan usaha, dan 3) Faktor sosiological, menyangkut hubungan dengan keluarga dan sebagainya, meliputi, hubungan atau relasi, tim yang dapat diajak kerjasama dalam berusaha, dorongan orangtua untuk membuka usaha, bantuan keluarga, dan pengalaman bisnis sebelumnya.

\section{Pandemi Covid-19}

Corona virus merupakan keluarga besar virus yang menyebabkan penyakit pada manusia dan hewan. Pada manusia biasanya menyebabkan penyakit infeksi saluran pernapasan, mulai flu biasa hingga penyakit yang serius seperti Middle East Respiratory Syndrome (MERS) dan Sindrom Pernafasan Akut Berat/ Severe Acute Respiratory Syndrome (SARS). Corona virus jenis baru yang ditemukan pada manusia sejak kejadian luar biasa muncul di Wuhan Cina, pada Desember 2019, kemudian diberi nama Severe Acute Respiratory Syndrome Corona virus 2 (SARS-COV2), dan menyebabkan penyakit Corona virus Disease-2019 (COVID-19). ${ }^{16}$

Corona virus adalah virus RNA besar beruntai tunggal positif, bukan hanya menginfeksi manusia, tetapi juga berbagai jenis hewan. Corona virus pertama kali dijelaskan pada tahun 1966 oleh Tyrell dan Bynoe. Berdasarkan morfologi corona virus sebagai virion bola dengan cangkang inti dan proyeksi permukaan menyerupai korona matahari. Disebut corona virus (bahasa Latin: korona = mahkota). Ada empat subfamili, yaitu alpha-, beta-, gamma- and delta- corona viruses. Di antara tujuh subtipe corona virus yang dapat menginfeksi manusia, beta-corona virus dapat menyebabkan penyakit dan kematian parah, sedangkan alpha-corona virus menyebabkan infeksi tanpa gejala atau gejala ringan. SARS-CoV-2 termasuk dalam garis keturunan dari beta-corona viruses dan terkait erat dengan virus SARS-CoV. Empat gen struktural utama mengkode protein nukleokapsid $(\mathrm{N})$, protein lonjakan $(\mathrm{S})$, protein membran kecil $(\mathrm{SM})$ dan membran glikoprotein $(\mathrm{M})$ dengan membran tambahan glikoprotein (HE) yang terjadi di HCoV-OC43 dan HKU1 beta-corona virus. SARS-CoV-2 adalah 96\% identik di seluruh tingkat genom dengan kelelawar corona virus. ${ }^{17}$

Wabah virus corona baru atau Corona Virus Disease 2019 (Covid-19) makin terasa dalam perekonomian dalam negeri, terutama dari sisi konsumsi, korporasi, sektor keuangan, dan Usaha Mikro Kecil Menengah (UMKM). Berdasarkan kajian Kementerian Keuangan (Kemenkeu), Covid-19 menimbulkan ancaman kehilangan

${ }^{16}$ Kementerian Kesehatan Republik Indonesia, “Tanya-jawab Coronavirus dan COVID19", https://covid19.kemkes.go.id/uncategorized/qna-pertanyaan-dan-jawaban-terkait-covid19/ Dikutip Pada Tanggal 1 April 2021.

${ }^{17}$ Thirumalaisamy P. Velavan \& Christian G. Meyer, “The COVID-19 epidemic. Tropical Medicine and International Health", 25(3), 278-280. https://doi.org/10.1111/tmi.13383 
pendapatan rumah tangga, tidak dapat bekerja untuk memenuhi kebutuhan hidup minimalnya. ${ }^{18}$

\section{METODOLOGI PENELITIAN}

Penelitian ini merupakan jenis penelitian kualitatif deskriptif. Pengumpulan data dilakukan dengan tiga cara yaitu, wawancara, observasi, dan studi dokumen. Wawancara dilakukan pada lima belas responden yang dipilih secara acak sesuai dengan tujuan penelitian. Wawancara dilakukan pada lurah Rabangodu Selatan, perwakilan perguruan tinggi, dan pelaku usaha sebagai komponen penting penerapan model triple helix. Dua belas responden dari masyarakat kelurahan Rabangodu Selatan sebagai orang yang terkena dampak penerapan model triple helix. Waktu penelitian empat bulan, dimulai dari Februari dan berakhir pada Mei 2021.

Analisis data menggunakan interactive model dengan tahapan sebagai berikut: (1) pengumpulan data, (2) reduksi data, (3) penyajian data, dan (4) penarikan kesimpulan. Pengujian keabsahan data menggunakan triangulasi data. Triangulasi data yang digunakan dalam penelitian ini adalah triangulasi teknik dan triangulasi sumber. Triangulasi teknik yaitu dengan menggunakan tiga teknik pengumpulan data, wawancara, observasi, dan studi dokumen. Triangulasi sumber yaitu dengan melakukan wawancara pada lebih dari tiga responden baik yang menerapkan model triple helix maupun yang terkena dampak penerapan model triple helix.

\section{HASIL PENELITIAN}

Model triple helix belum mampu meningkatkan minat berwirausaha masyarakat kelurahan Rabangodu Selatan pada masa pandemi covid-19. Berdasarkan tiga faktor pendorong minat berwirausaha yaitu (1) faktor personal. Masyarakat kelurahan Rabangodu Selatan memiliki motivasi dalam memulai usaha, hal ini disebabkan beberapa faktor seperti tidak ada penghasilan tetap pada masa pandemi, peningkatan jumlah pengangguran, kebutuhan keluarga meningkat, dan keinginan mandiri dengan membangun usaha sendiri, namun karena keterbatasan modal dan penumpukkan hutang, sebagian besar warga belum berani berwirausaha, (2) faktor environment. Keterbatasan wadah pelatihan kewirausahaan pada masa pandemi baik dari lingkungan formal (pemerintah) dan non-formal (swasta) menjadi faktor kurangnya minat masyarakat Rabangodu Selatan dalam berwirausaha. Kebijakan pemerintah baik pusat maupun daerah pada masa pandemi dianggap kurang memihak pada dunia wirausaha (pedagang kecil) seperti diberlakukan lockdown, PSBB (Pembatasan Sosisal Berskala Besar), dan PPKM (Pemberlakuan Pembatasan Kegiatan Masyarakat) darurat seiring peningkatan jumlah pasien covid di Kota Bima. Kurangnya kebijakan pemerintah daerah dalam membantu pembangunan dan pengembangan wirausaha di Kota Bima saat masa pandemi juga menjadi faktor kurangnya minat berwirausaha

${ }^{18}$ Fakhri Hermansyah, "Menghitung dampak Covid-19 terhadap usaha Hingga UMKM", https://www.msn.com/id-id/berita/nasional/menghitung-dampak-covid-19-terhadap-duniausaha-hingga-umkm/ar-BB120z4L Dikutip Pada Tanggal 1 April 2021. 
masyarakat Rabangodu Selatan, (3) faktor sosiological. Beberapa warga telah memiliki pengalaman berwirausaha sebelumnya, namun karena beberapa faktor seperti hutang, berladang atau bertani di tempat jauh, dan berganti profesi mengharuskan warga menghentikan sementara kegiatan berwirausaha. Namun, pada masa pandemi covid-19 warga cukup kesulitan dalam menjalin relasi peminjaman modal baik dengan lingkungan internal (keluarga) maupun eksternal. Bantuan pemerintah pusat hanya diperuntukkan bagi masyarakat yang telah memiliki usaha dengan kriteria tertentu, tidak untuk masyarakat yang ingin memulai usaha.

\section{PENUTUP}

\section{Kesimpulan}

Model triple helix belum mampu meningkatkan minat berwirausaha masyarakat kelurahan Rabangodu Selatan pada masa pandemi covid-19 berdasarkan tiga faktor yaitu: (1) faktor personal, (2) faktor environment, (3) faktor sosiological.

\section{Rekomendasi}

Pemerintah Kota Bima dan pemerintah kelurahan Rabangodu Selatan dapat menyiapkan wadah guna mengembangkan minat berwirausaha masyarakat, pengadaan sarana dan prasarana memadai, peminjaman modal usaha, memberikan akses inofrmasi luas dan menyeluruh tentang kewirausahaan dan penggunaan teknologi dalam berwirausaha, melakukan kerjasama dengan perusahaan dan perguruan tinggi di bidang kewirausahaan, serta melakukan monitoring dan evaluasi berkelanjutan terhadap kegiatan pembangunan dan pengembangan kewirausahaan di Kota Bima terutama pada masa pandemi covid-19.

Perguruan tinggi dapat lebih fokus dalam melakukan salah satu tri dharma perguruan tinggi dengan mengabdikan diri pada masyararakat di bidang kewirausahaan. Berbagi tentang ilmu dan informasi kewirausahaan, inovasi, dan penggunaan teknologi dalam kewirausahaan terutama pada masa pandemi covid-19.

Swasta atau perusahaan dapat lebih berperan aktif dalam berbagi ilmu, informasi, kreatifitas, dan inovasi dalam memulai, menjalankan, dan mempertahankan sebuah usaha. Jika memungkinkan, perusahaan dapat memberikan pinjaman modal dan memberdayakan masyarakat untuk menjadi mitra usaha, melakukan pembinaan dan pelatihan sehingga masyarakat dapat dengan mandiri membuka usaha guna membantu memenuhi kebutuhan ekonomi keluarga dan mengurangi angka pengangguran di kelurahan Rabangodu Selatan. 


\section{DAFTAR PUSTAKA}

Alma, B. (2013). Kewirausahaan untuk mahasiswa dan umum. Bandung: Alfabeta.

Anjaeni, R. (2020). Sri Mulyani ungkap tiga masalah ekonomi yang disebabkan pandemi Covid19. Kontan.Co.Id. https://nasional.kontan.co.id/news/sri-mulyani-ungkap-tigamasalah-ekonomi-yang-disebabkan-pandemi-covid-19?page=all

BPS Kota Bima. (2020). Kecamatan Raba dalam Angka 2020. https://bimakota.bps.go.id/publication/2020/09/28/ac0af0b60ed610b921be4419 / kecamatan-raba-dalam-angka-2020.html

Daulay, Z. A. A. (2018). Strategi Pengembangan Ekonomi Kreatif Dengan Metode Triple Helix (Studi Pada UMKM Kreatif di Kota Medan). TANSIQ: Jurnal Manajemen Dan Bisnis Islam, 1(1).

Dinas Koperindag Kota Bima. (2021a). Data Rabangodu Selatan.

Dinas Koperindag Kota Bima. (2021b). Rekap Data 2018-2021 Untuk Inspektorat.

Etzkowitz, H., \& Leydesdorff, L. (1995). a Laboratory for Knowledge Based Economic Development. EASST Review, 14(1), 14-19.

Hendro. (2011). Dasar-Dasar Kewirausahaan. Erlangga.

Hermansyah, F. (2020). Menghitung dampak Covid-19 terhadap usaha Hingga UMKM. Kontan.co.id. https://www.msn.com/id-id/berita/nasional/menghitungdampak-covid-19-terhadap-dunia-usaha-hingga-umkm/ar-BB120z4L

Kementerian Kesehatan Republik Indonesia. (2020). Tanya-jawab Coronavirus dan COVID-19. https://covid19.kemkes.go.id/uncategorized/qna-pertanyaan-danjawaban-terkait-covid-19/

Lawton Smith, H., \& Leydesdorff, L. (2014). The Triple Helix in the context of global change: dynamics and challenges. Prometheus, 32(4), 321-336. https://doi.org/10.1080/08109028.2014.972135

Pemerintah Propinsi NTB. (2021). DATA COVID-19 Dinas Kesehatan NTB. https://corona.ntbprov.go.id/

Rusdiana, A. (2018). Kewirausahaan: Teori dan Praktek. Pustaka Setia.

Utami, H. N., Sandra, S., \& Ruhana, I. (2019). Pemberdayaan Masyarakat dengan Pendekatan Triple Helix untuk Pengembangan Kompetensi Wirausaha Masyarakat Desa Mandiri Energi. Jurnal Ilmiah Administrasi Publik, 5(3), 294-302. https://doi.org/10.21776/ub.jiap.2019.005.03.5

Velavan, T. P., \& Meyer, C. G. (2020). The COVID-19 epidemic. Tropical Medicine and International Health, 25(3), 278-280. https://doi.org/10.1111/tmi.13383

Wahjusaputri, S., Fitriani, S., Dipenogoro, A., \& N. Indah, T. (2018). Model Pengembangan Ekonomi Kreatif Berbasis Triple Helix Bagi UKM Di Provinsi Jawa Barat. 
Wedayanti, N., \& Giantari, I. (2016). Peran Pendidikan Kewirausahaan Dalam Memediasi Pengaruh Norma Subyektif Terhadap Niat Berwirausaha. E-Jurnal Manajemen Universitas Udayana, 5(1), 255039.

Wuryandani, D. (2020). Dampak Pandemi Covid-19 terhadap Pertumbuhan Ekonomi Indonesia 2020 dan Solusinya. Kajian Strategis terhadap Isu Aktual dan Strategis, XII(15), 19-24. 